\title{
Customer Satisfaction, Efficiency, and Capital Structure as Determinants of Performance Transportation Companies in Indonesia
}

\author{
Mursalim \\ Faculty of Economic and Business, Hasanuddin University, Indonesia \\ Jalan Perintis Kemerdekaan KM. 10, Makassar 90245 \\ Abdullah Sanusi \\ Faculty of Economic and Business, Hasanuddin University, Indonesia \\ Jalan Perintis Kemerdekaan KM. 10, Makassar 90245 \\ Hendragunawan S. Thayf \\ Faculty of Economic and Business, Hasanuddin University, Indonesia \\ Jalan Perintis Kemerdekaan KM. 10, Makassar 90245 \\ Nur Alamzah \\ Faculty of Economic and Business, Hasanuddin University, Indonesia \\ Jalan Perintis Kemerdekaan KM. 10, Makassar 90245
}

Doi:10.5901/mjss.2017.v8n1p123

\section{Abstract}

This study aimed to describe the influence of customer satisfaction, efficiency and optimal capital structure to the increase of the performance of transportation companies in Indonesia. The study was designed in the relationship between variables. The data used is secondary data obtained from the Indonesian Capital Market Directory (ICMD) and the website of 22 companies that were used as samples for 3 years. Data were analyzed using descriptive and inferential statistics analysis to test the hypothesis. The result showed that the efficiency affected customer satisfaction and was reflected in the sales growth of the company. However, it did not have an impact on the level of capital structure as reflected in DER and the performance which reflected in $R O A$. We also found that there was an indirect effect on the efficiency of the capital structure and performance through customer satisfaction. We also found that there is a significant indirect influence on the efficiency and the performance through customer satisfaction and capital structure. Customer satisfaction capital affects the structure. When customer satisfaction is high, which is reflected in higher sales growth aspect, it will have an impact on the high capital structure, which is reflected in DER. The result shows that customer satisfaction has an effect on the performance. When customer satisfaction is high, which is reflected in higher sales growth aspect, it will have an impact on the high performance, which is reflected in aspects of ROA. The result also indicates that capital structure affects the performance. When a capital structure is high, which is reflected by the high DER aspects, it will impact on the high performance, which is reflected on aspects of ROA.

Keywords: customer satisfaction, efficiency, capital structure, performance

\section{Introduction}

The intention of the Indonesian government to put the transport sector as a driving force of development by reducing regional disparities remains to be difficult to realize (Wenyra, 2012). The low performance of the transport sector due to the limited financial support from the banking and non-bank financial institutions. Support for financial institutions as a source of capital or capital structure for the transport sector is expected to boost the performance of transportation 
services provider. Jusman Syafii Djamal in Wino and Oky (2010) explains that the lack of support from financial institutions to the transport sector for the transportation industry is still considered a high-risk business sector (high risk) and low yielding.

The external environment such as macroeconomic factors are changing rapidly has also influenced the development of the transport sector's performance. On the internal side, the weakening of the exchange rate in the short term will have an impact on the increase in some imported components associated with the transportation infrastructure which encourages the growth of operating expenses. The influence of market risk shown by the global economic downturn along with unstable Indonesian macroeconomic factors such as fluctuations in the exchange rate, the increase in the price of the component of transportation advocates a direct impact on corporate performance as measured by profitability and stock price (Zaldi Masita, 2010).

Research on the determinants of the company's performance in the transportation sector is more focused on technical aspects such as vehicles license (car, aircraft, ships) or other physical factors whereas attention to management factors are relatively less. The performance of the transport sector is a picture of a manager's success in using available resources both physical and non-physical resources. The main idea of the need for the transport sector performance indicators is to provide a clear framework for self-evaluation which is based on the model of management by results and management by objective. Aworemi and llori (2008) explains that the company's performance is influenced by a number of transport sectors such as employees, government regulations on fuel and spare parts, maintenance $I$ operations, road infrastructure, the lifecycle of the equipment, and the effects of telecommunications (Aworemi and llori, 2008). The company's decision to expand geographically based not only on strategic marketing considerations relating to the marketing area, but also a positive impact on the management of the company. Businesses with wider marketing area (several countries) have a chance to get a manager who has the managerial abilities better than companies that only serve the region or a certain country (Blanquart and Burmeister, 2009).

In the meantime, research conducted by Murty et al., (2013) found that there are several factors that can improve the performance of companies and transport sectors, particularly air transport, including application outsourcing system, types of business models, ownership and control, and policy liberalization. Advanced transportation systems can help the firm to develop the concept of performance that leads to the ability to provide satisfaction in order to meet the needs of customers. It required several determinants of performance, such as infrastructure, technology, operational, economic, environmental, social, and policy related to performance (Janic', 2014).

\section{Theoretical Framework and Hypotheses}

\subsection{Performance}

The performance assessment is the determination of the periodic operational effectiveness of an organization, part of the organization, and employees based on goals, standards, and performance is superbly predetermined (Mulyadi, 2007). Performance in principle is a feat achieved by the company in a given period which reflects the level of health of the company. Performance may be referred to as a measure of how efficiently and effectively a manager or a company, how well managers or organizations that achieve the goals of adequate (Winarni and Sugiarso, 2005). Therefore, the performance is also a description of the achievement of the implementation of an activity / program / policy in realizing the goals, objectives, mission and vision of the organization. A list of what you want to achieve stated in the formulation of strategic planning of an organization.

\subsection{Customer satisfaction}

The increasing demand for transportation services in the community, not only will impact on the growing number of companies engaged in the transport sector but will also lead to stiff competition. Building and maintaining customer satisfaction is a good step that can be applied by the company to remain competitive and market share.

Kotler (2000) outlines that consumers form an expectation of value and act on it, the fact whether an offer would meet the expectations of consumers affect the value and the likelihood they will buy back. The buyer will buy back the company that is considered to offer high customer value delivery. Customer satisfaction is the customer response to the correspondence between the previous interest rate and the actual performance that is felt after application. Customer satisfaction is determined by the quality of products / services desired customer, so the quality assurance a top priority for any company that is currently used as a benchmark in a particular competitive advantage of companies (Supranto, 2001).

Research conducted by Williams and Naumann (2011) found a significant relationship between customer 
satisfaction and financial performance and marketing. More specifically stated that there is a strong influence on customer satisfaction and retention, receipts, earnings per share, stock price, and Tobin's q. Similar results were also found previously in studies Boselie, P. and Van der Wiele (2001); Chi and Gursoy (2009).

\subsection{Efficiency}

Efficiency in the economic concept referring to a number of concepts related to the use, as well as maximizing the use of all resources in the production process of goods and services. The use of resources can be said to be efficient if: (1) All of the resources available are fully utilized; (2) The style of the user is already exist and there are no longer any other usage patterns that will provide additional prosperity for society or individual. Efficiency in the production concept tends to assess the technical and operational, so that the efficiency in the production concept is generally seen from a technical standpoint and cost (Sadono, 2008).

Efficiency is achieved when the same input produces greater output, with a smaller input produces the same output, and with a large input to produce a greater output. Several studies have revealed a link between the company's efficiency and company performance. Fairfield and Yohn (2009) revealed that the changes in return on net operating assets and change in profit margin and asset turnover changes to affect the ability of the profits (profitability). Similar results were found by Nissim and Penman (2001); Penman and Zhang (2003); and Soliman (2008).

\subsection{Capital structure}

Capital structure is a mix or a combination of debt and equity capital that companies use to fund its business (Damodaran, 2001). The optimal capital structure is a combination of equity that maximizes the company's stock price (Brigham and Houston, 2009). The influence of capital structure to the company's performance can be found in several empirical studies that have been conducted by previous researchers as Akinyomi (2013). In his research, Akinyomi finds a strong correlation between capital structure and corporate performance. The capital structure is measured using indicators of debt to capital, debt to common equity, short-term debt to total debt and the age of the firms' performance while the company is measured by return on assets and return on equity. However, other studies found no significant relationship between the capital structure to the company's performance as Oke and Afolabi (2011) and Babalola (2014).

Based on the theoretical basis and conceptual framework, the researcher took hypothesis as follows:

$\mathrm{H}_{1}$ : Efficiency significantly affects on customer satisfaction

$\mathrm{H}_{2}$ : Efficiency significantly affects on capital structure

$\mathrm{H}_{3}$ : Efficiency significantly affects on performance

$\mathrm{H}_{4}$ : Customer satisfaction significantly affects on capital structure

$\mathrm{H}_{5}$ : Customer satisfaction significantly affects on performance

$\mathrm{H}_{6}$ : Capital structure significantly affects on performance

$\mathrm{H}_{7}$ : Customer satisfaction mediate the effect of efficiency on capital structure

$\mathrm{H}_{8}$ : Customer satisfaction mediate the effect of efficiency on performance

$\mathrm{H}_{9}$ : Capital structure mediate the effect of efficiency on performance

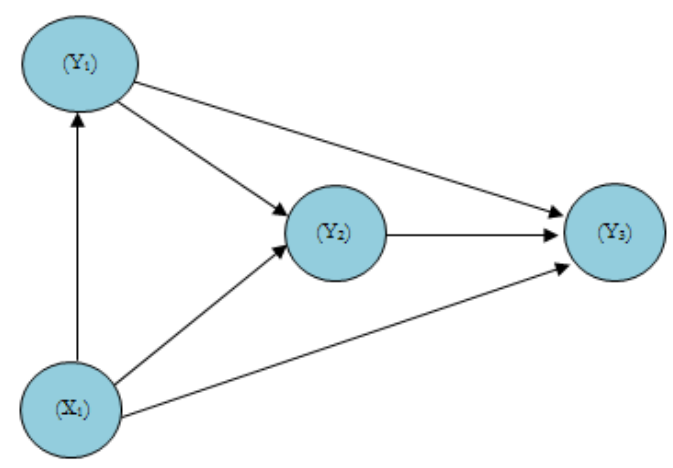

Figure 1 Conceptual framework 


\section{Methodology}

\subsection{Sample and procedure}

Data used in this study were collected through the Indonesian Capital Market Directory (ICMD), and the Annual Report (Annual Report) of the sample companies. The population of this research is all transportation companies listed in Indonesia Stock Exchange using saturated sample (census). The number of companies transportation appears logical as shown in Table 1.

Table 1: Profile of sample

\begin{tabular}{clc}
\hline No & Description & Quantity \\
\hline $\mathbf{1}$ & Emiten & 525 \\
$\mathbf{2}$ & Transportation companies that publish financial report regularly & 32 \\
$\mathbf{3}$ & Transportation companies that publish financial report regularly in 2013 - 2015 & 22 \\
& Sample & 22 \\
\hline
\end{tabular}

Source: Mursalim et al., (2016)

\subsection{Methods of data analysis}

In analyzing the data, this study emphasizes the quantitative analysis. The data analysis with a quantitative approach was divided into descriptive statistical analysis and inferential statistics.

1. Descriptive statistical analysis

The analysis is used to describe the study variables. The data have been collected are then tabulated in tables and discussions were held descriptively presented in the form of frequency distribution and average statistics.

2. Analysis of inferential statistics (hypothesis testing)

In this research, we employed Structural Equation Modeling (SEM) variance-based method known as Partial Least Square (PLS).

\subsection{Operational definitions}

Performance describes the ability of a transport company in acquiring profit from its assets. In this study, the performance is measured using the ratio of ROA with the consideration that the assets or facilities and infrastructure for the transport company becomes a strategic resource to optimize their activities.

Customer satisfaction is the satisfaction felt by the users of transport services. The higher level of customer satisfaction, the better for the company. In this research, customer satisfaction is reflected in the form of increased sales.

Efficiency indicates the ability of a transport company in managing its operations. Efficiency can be measured by comparing the operating income with operating costs. The efficiency ratio also indicates the proportion of revenue from the company to the costs incurred.

Capital structure is the composition of capital used by the company to run its operations. This is measured by comparing the ratio between debt and equity of the company. The capital structure of the company is measured by comparing the company's debt to equity

\section{Data Analysis and Discussion}

\subsection{Data Analysis}

\subsubsection{Descriptive statistics}

The strategic role of the company transport sector in Indonesia can only be optimal if the company performs well. In this study, we stated that the performance of transportation companies in Indonesia for the period 2013-2015 and is determined by customer satisfaction, efficiency, and capital structure. 
Table 2: Trend of Satisfied and Unsatisfied of Firms

\begin{tabular}{|c|c|c|c|}
\hline \multirow{2}{*}{ Description } & \multicolumn{3}{|c|}{ Period (Year) } \\
\cline { 2 - 4 } & 2013 & 2014 & 2015 \\
\hline \multirow{2}{*}{ Satisfied } & 14 & 13 & 7 \\
\cline { 2 - 4 } & $64 \%$ & $59 \%$ & $32 \%$ \\
\hline \multirow{2}{*}{ Unsatisfied } & 8 & 9 & 15 \\
\cline { 2 - 4 } & $36 \%$ & $41 \%$ & $68 \%$ \\
\hline \multirow{2}{*}{ Total } & 22 & 22 & 22 \\
\cline { 2 - 4 } & $100 \%$ & $100 \%$ & $100 \%$ \\
\hline
\end{tabular}

Source: Data proceed, Mursalim et al., (2016)

In Table 2, it appears that during the study period 22 issues that used as the sample showed a relative decrease in performance. In 2013 the number of companies that positive sales growth as much as 14 or 64 percent decreased to 13 or 59 percent in 2014 and 2015 dropped to only 7 or 32 percent. Variables associated with this study, the illustration shows that the decline in satisfaction with the services provided by the company.

Table 3: Trend of efficient and inefficient of Firms

\begin{tabular}{|c|c|c|c|}
\hline \multirow{2}{*}{ Description } & \multicolumn{3}{|c|}{ Period (Year) } \\
\cline { 2 - 4 } & 2013 & 2014 & 2015 \\
\hline \multirow{2}{*}{ Efficient } & 21 & 19 & 18 \\
\cline { 2 - 4 } & $95 \%$ & $86 \%$ & $82 \%$ \\
\hline \multirow{2}{*}{ Inefficient } & 1 & 3 & 4 \\
\cline { 2 - 4 } & $5 \%$ & $14 \%$ & $18 \%$ \\
\hline \multirow{2}{*}{ Total } & 22 & 22 & 22 \\
\cline { 2 - 4 } & $100 \%$ & $100 \%$ & $100 \%$ \\
\hline
\end{tabular}

Source: Data proceed, Mursalim et al., (2016)

Table 3 illustrates the trend of efficient and inefficient of issuers during the period $2013-2015$. In the table, it appears that during the study period the number of the company that operates efficiently is decreasing from 21 to 18 . In 2013 the number of companies that operate efficiently is 21 or 95 percent decreased to 19 or 86 percent of the company in 2014 and 18 or 82 percent of the company in 2015 . This illustrates the deterioration of the performance of companies from the transport sector in Indonesia in $2013-2015$.

Table 4 shows the trend of profit and loss company transport sector 2013-2015 period. Along with the customer satisfaction, variables such as efficiency and capital structure of the companies in the transport sector in Indonesia during the period 2013-2015, which was measured by ROA indicators also tend to decrease compared to the previous periods. Based on these images can be noted that the last three years the transport sector companies ability to manage its assets to obtain profits have decreased.

Table 4: Trend of profit and loss of Firms

\begin{tabular}{|c|c|c|c|}
\hline \multirow{2}{*}{ Description } & \multicolumn{3}{|c|}{ Period (Year) } \\
\cline { 2 - 4 } & 2013 & 2014 & 2015 \\
\hline \multirow{2}{*}{ Profit } & 18 & 15 & 11 \\
\cline { 2 - 4 } & $82 \%$ & $68 \%$ & $50 \%$ \\
\hline \multirow{2}{*}{ Loss } & 4 & 7 & 11 \\
\cline { 2 - 4 } & $18 \%$ & $32 \%$ & $50 \%$ \\
\hline \multirow{2}{*}{ Total } & 22 & 22 & 22 \\
\cline { 2 - 4 } & $100 \%$ & $100 \%$ & $100 \%$ \\
\hline
\end{tabular}

Source: Data proceed, Mursalim et al., (2016)

The decision to expand made the companies change their capital structure. Limited capital for expansion encourages 
companies to choose between using debt or equity. As seen in Table 5, that in 2013 and 2014, 19 companies or 86 percent that use debt greater than equity. Furthermore, in 2015 the number of companies that use debt greater than equity increased to 20 or 91 percent. The increasing of the proportion of debt used compared to equity showed an increased confidence of external parties, especially suppliers and financial institutions such as banks.

Table 5: Trend of leverage and unleveraged of Firms

\begin{tabular}{|c|c|c|c|}
\hline \multirow{2}{*}{ Description } & \multicolumn{3}{|c|}{ Period (Year) } \\
\cline { 2 - 4 } & 2013 & 2014 & 2015 \\
\hline \multirow{2}{*}{ Levered } & 19 & 19 & 20 \\
\cline { 2 - 4 } & $86 \%$ & $86 \%$ & $91 \%$ \\
\hline \multirow{2}{*}{ Unleveraged } & 3 & 3 & 2 \\
\cline { 2 - 4 } & $14 \%$ & $14 \%$ & $9 \%$ \\
\hline \multirow{2}{*}{ Total } & 22 & 22 & 22 \\
\cline { 2 - 4 } & $100 \%$ & $100 \%$ & $100 \%$ \\
\hline
\end{tabular}

Source: Data proceed, Mursalim et al., (2016)

\subsubsection{Linearity test and $Q^{2}$ Predictive}

Linearity test was performed to test whether there is a linear relationship between variables. Testing the assumption of linearity using curve fit performed with SPSS software. References used is the principle of parsimony, i.e. (1) where the significant linear model, or (2) when the whole model is perhaps nonsignificant. Specifications of the model used as the basis of the test is a model of linear, quadratic, cubic, inverse, logarithmic, power, S, compound, and exponential growth. The two provisions indicate the assumption of linearity met. The following table presents the results of testing the linearity of the relationship between variables:

Table 6: Testing of linearity assumptions

\begin{tabular}{|c|c|c|}
\hline Correlations & Testing results & Remarks \\
\hline$X_{1} \rightarrow Y_{1}$ & Model Linear Significant (Sig Linear $0.000<0.05)$ & Linear \\
\hline$X_{1} \rightarrow Y_{2}$ & Model Linear Significant (Sig Linear $0.000<0.05)$ & Linear \\
\hline$X_{1} \rightarrow Y_{3}$ & Model Linear Significant (Sig Linear $0.000<0.05)$ & Linear \\
\hline$Y_{1} \rightarrow Y_{2}$ & Model Linear Significant (Sig Linear $0.049<0.05)$ & Linear \\
\hline$Y_{1} \rightarrow Y_{3}$ & Model Linear Significant (Sig Linear $0.000<0.05)$ & Linear \\
\hline$Y_{2} \rightarrow Y_{3}$ & Model Linear Significant (Sig Linear $0.000<0.05)$ & Linear \\
\hline
\end{tabular}

Sources: Data analysis with SPSS, Mursalim et al., (2016)

Table 6 shows seventh relationship between variables meet all significant linear model assumptions for a sig ( $p$-value) linear model is smaller than 0.05 . Thus, the four relationships between variables in this study are in linear form. Examination of the goodness of fit model in PLS can be seen from the predictive value-relevance $\left(Q^{2}\right)$. $Q^{2}$ value calculated based on the value of $R^{2}$ of each endogenous variable as follows:

1. Measurement of the customer satisfaction endogenous variable $\left(Y_{1}\right)$, obtained $R^{2}$ of $0.1621 \%$ or 16.21 . This indicates that customer satisfaction $\left(Y_{1}\right)$ of $16.21 \%$ influenced by the efficiency $\left(X_{1}\right)$.

2. Measurement of endogenous variable capital structure $\left(Y_{2}\right)$, obtained $R^{2}$ of 0.3395 or $33.95 \%$. This indicates that the capital structure $\left(\mathrm{Y}_{2}\right)$ amounted to $33.95 \%$ influenced by the efficiency $\left(\mathrm{X}_{1}\right)$ and customer satisfaction $\left(Y_{1}\right)$.

3. Measurement of endogenous variable performance $\left(Y_{3}\right)$, obtained $R^{2}$ of 0.6032 or $60.32 \%$. This indicates that the performance $\left(Y_{3}\right)$ amounted to $60.32 \%$ influenced by the efficiency $\left(X_{1}\right)$, customer satisfaction $\left(Y_{1}\right)$ and capital structure $\left(\mathrm{Y}_{2}\right)$.

Thus the relevance predictive value $\left(Q^{2}\right)$ is obtained as follows:

$Q^{2}=1-\left(1-R_{12}\right)\left(1-R_{22}\right)\left(1-R_{32}\right)\left(1-R_{42}\right)$

$Q^{2}=1-(1-0.1621)(1-0.3395)(1-0.6032)$

$\mathrm{Q}^{2}=0.7804$ 
Relevance predictive value of $78.04 \%$ indicates that the diversity of data that can be explained by the PLS model built amounted to $78.04 \%$, while the remaining $21.96 \%$ is explained by other variable (which is not contained in the model) and error.

\subsubsection{Direct effect and Indirect effect (Testing hypothesis)}

Hypothesis testing is done by using the coefficient value and $p$-value of the direct and indirect effects of each variable. By watching the coefficient value and $p$-value as shown in Table 6 , it can be concluded that out of 6 (six) direct influence hypothesized only 4 (four) are accepted ie $\mathrm{H}_{1}, \mathrm{H}_{3}, \mathrm{H}_{4}, \mathrm{H}_{5}$, and $\mathrm{H}_{6}$ while 2 (two) hypotheses other rejected each $\mathrm{H}_{2}$ and $\mathrm{H}_{3}$.

Table 7: Testing of direct effect

\begin{tabular}{|c|l|c|c|c|c|}
\hline No & Effect & Coefficient & t-statistic & P-value & Hypothesis \\
\hline 1 & Efficiency $\left(\mathrm{X}_{1}\right)$ on customer satisfaction $\left(\mathrm{Y}_{1}\right)$ & 0.403 & 6.075 & 0.000 & Accepted \\
\hline 2 & Efficiency $\left(\mathrm{X}_{1}\right)$ on capital structure $\left(\mathrm{Y}_{2}\right)$ & 0.085 & 1.034 & 0.301 & Rejected \\
\hline 3 & Efficiency $\left(\mathrm{X}_{1}\right)$ on Performance $\left(\mathrm{Y}_{3}\right)$ & 0.046 & 0.505 & 0.614 & Rejected \\
\hline 4 & Customer satisfaction $\left(\mathrm{Y}_{1}\right)$ on Capital structure $\left(\mathrm{Y}_{2}\right)$ & 0.543 & 5.081 & 0.000 & Accepted \\
\hline 5 & Customer satisfaction $(\mathrm{Y} 1)$ on Performance $\left(\mathrm{Y}_{3}\right)$ & 0.259 & 3.229 & 0.001 & Accepted \\
\hline 6 & Capital structure $(\mathrm{Y} 2)$ on Performance $\left(\mathrm{Y}_{3}\right)$ & 0.579 & 3.705 & 0.000 & Accepted \\
\hline
\end{tabular}

Sources: Data analysis with PLS, Mursalim et al., (2016)

The indirect effect between variable was analyzed using the count results as shown in Table 8. Based on the table, it can be concluded that the three (3) direct influence as has been hypothesized been accepted.

Table 8: Indirect effect of variable

\begin{tabular}{|c|c|c|c|c|}
\hline \multicolumn{1}{|c|}{ Indirect effect } & \multicolumn{2}{|c|}{$\begin{array}{c}\text { Coefficient of } \\
\text { Direct effect }\end{array}$} & Coefficient of Indirect effect & Hypothesis \\
\hline$X_{1} \rightarrow Y_{1} \rightarrow Y_{2}$ & $X_{1} \rightarrow Y_{1}=0.403^{*}$ & $Y_{1} \rightarrow Y_{2}=0.543^{*}$ & $\begin{array}{c}0.219 \\
\text { Significant }\end{array}$ & Accepted \\
\hline$X_{1} \rightarrow Y_{1} \rightarrow Y_{3}$ & $X_{1} \rightarrow Y_{1}=0.403^{*}$ & $Y_{1} \rightarrow Y_{3}=0.259^{*}$ & $\begin{array}{c}0.104 \\
\text { Significant }\end{array}$ & Accepted \\
\hline$X_{1} \rightarrow Y_{1} \rightarrow Y_{2} \rightarrow Y_{3}$ & $X_{1} \rightarrow Y_{1}=0.403^{*}$ & $Y_{1} \rightarrow Y_{2}=0.543^{*}$ & $\begin{array}{c}0.127 \\
\text { Significant }\end{array}$ & Accepted \\
\cline { 2 - 3 } & \multicolumn{2}{|c|}{$Y_{2} \rightarrow Y_{3}=0.579^{*}$} &
\end{tabular}

Sources: Data analysis with PLS, Mursalim et al., (2016)

\subsection{Hypothesis Testing}

\subsubsection{The effect of efficiency on customer satisfaction}

Efficiency for any company is not just an attempt to optimize the ratio of earned income to the costs incurred in a transaction. Efficiency has contributed in the creation of company's competitiveness. The competitive company is able to obtain higher profits compared with the average of the industry (Porter, 1980).

Revenue is strongly associated with the use of operational costs. The higher the income earned compared to the costs incurred, the more efficient the company's operations. An Efficient company will set a price lower than its competitors. Price for consumers is one of the considerations in deciding to consume a product or service being offered.

In a competitive situation, the customer will get a different satisfaction from consuming a product or service that the quality is the same but with different prices. The results of this study showed that the more efficient the higher the company's customer satisfaction was measured using the sales growth. The results support the research Leuthauser and Weaver (2006) and Reinwald (2013) which found a direct influence on the efficiency and customer satisfaction. Efficiency tactics that can be done by the company are operating inefficiency, technical efficiency, or efficiency. 


\subsubsection{The effect of efficiency on capital structure}

The analysis showed that efficiency does not significantly influence the company's capital structure. These results differ from the study by Berger and Bonaccorsi di Patti (2006). They explain that the influence of the efficiency of the capital structure can be analyzed from two different hypothesis, namely efficiency-risk hypothesis, and franchise-value hypothesis. Efficiency-risk hypothesis explains that more efficient firms will choose to use a large debt ratio since the company's efficiency will reduce the expected costs of bankruptcy and financial distress. But the results of this study differs from other research that was built with a franchise-value hypothesis. In the hypothesis explained that the company is operating efficiently will reduce the use of debt to protect the economic rents derived from higher efficiency from the possibility of liquidation.

\subsubsection{The effect of efficiency on performance}

Efficiency is one of the concerns for companies to generate long-term profitability. Companies as the profit oriented and has long-term vision entity, should ensure that each expenditure must be effective and efficient. Efficiency is not just the demands of companies on an individual basis but also the attention of the business world in the middle of the competition. Consideration is open only advantage but for the survival of the company. However, the results showed that efficiency does not affect the performance of the transport company in Indonesia during the period 2013-2015. In other words, the income earned by the transport companies is still low compared to the costs and therefore, can not improve its performance which is measured by ROA. In other words, the transport company profits gained through the management of its assets have been indirectly affected by the level of efficiency. These findings do not support the idea Blanquart and Burmeister (2009) which states that the transport company's performance is determined by a number of variables that are not only technical but also be assessed from the aspect of the economy and business-like efficiency.

\subsubsection{The effect of customer satisfaction on capital structure}

Previous studies have found that many factors affect the capital structure of the company. Vergas et., al (2015) identified six factors that affect the capital structure, namely tangibility, profitability, tax optimization, size, growth opportunities and market valuation of the company. Customer satisfaction in this study was measured by sales growth was positive customer response to the product or service offered by the company. The results showed that customer satisfaction significant positive effect on capital structure. This means that the higher the sales growth as a reflection of customer satisfaction, the higher the company's need to expand so that the capital requirements of several sources such as debt will be higher. The results are consistent with research Vergas et., al (2015) which states that sales growth positive effect on capital structure. But the results of this study differ from research Ahmed Sheikh and Wang (2011) found that the presence of negative influences between sales growth as outlined in the variable profitability and earnings volatility.

\subsubsection{The effect of customer satisfaction on performance}

Companies are not only required to build a relationship between the customer to be loyal, but the attention to customer satisfaction has also become a way for companies to save costs, especially to get new customers so this is an effective way to improve the company's profitability (Feng and Yanru, 2013).

Results showed significant positive effect between Customer satisfaction with the performance. Based on this it can be said that the higher the customer satisfaction, the better the performance of the company. These findings indicate that customer satisfaction is reflected by the growth in sales is able to improve the performance of the transport sector enterprises. The findings of this study support research Zang and Fei (2009) and Prakarsa and Tarigan (2013) who found a significant positive relationship between customer satisfaction and performance.

\subsubsection{The effect of capital structure on performance}

Studies on the effect of capital structure on the company's performance have been a critical issue of financial literature. Modigliani and Miller (1958) stated that the capital structure does not determine the value of the company. Modigliani and Miller's research assumes perfect capital market characterized by highly competitive, no taxes, no transaction costs, and investors have the same expectation of the return and risk of the company. In these conditions, Modigliani and Miller argued that capital structure does not affect the value of the company. However, in subsequent studies, Modigliani and 
Miller actually found the opposite result where the capital structure affect the performance of the company.

The results of this study revealed a significant positive effect on a capital structure with the performance of the transport company in Indonesia during the period 2013 - 2015. Based on these findings, it can be concluded that the higher the company's capital structure the higher the performance of the company. These results indicate that the performance of the transport company is strongly influenced by the ratio of debt to equity. This means that the use of debt or equity in running the company's operations can improve performance. The findings in this study support the research Hussain et al., (2014) and Akeem et al., (2014) who found a significant positive effect on capital structure and performance.

\subsubsection{The effect of efficiency on capital structure mediated customer satisfaction}

The company decisions to expand impact on increasing the availability of funds need. It's different with new entrants, the growth firms or at mature cycle has excessed to obtained funds from the investor. The decision of firm will directly effect on capital structure. Besides that, efficient firm operationalize is expected to be one of the capital sources moreover if efficiency was done encourages sales increase.

This research result indicates that customer satisfaction mediate the influence of efficiency against a capital structure. This shows that the capital structure of a transportation company in Indonesia increase if the efficiency could increase customer satisfaction. In other words that efficiency of companies resulting in the price of the products or services in relative terms competes with other companies, it will improve customer satisfaction that is represented by sales growth. An increase in customer satisfaction will encourage the company to use a capital source of debt is relatively greater than as equity.

\subsubsection{The effect of efficiency on performance mediated customer satisfaction}

An effort to respond the competition will encourage company created the advantage with products and services given. The advantage created by the company can be done by the emphasis the quality of the products. But standardization quality products at the same market encourage the company to focus on other dimensions as price. With the same quality, a customer will earn satisfaction more if to get products or services needed to be paid at a lower price. Companies to apply the competitive price compared with competitors will into a superior.

This research result indicates that customer satisfaction can mediate the influence of efficiency on performance. A company that performing and superior in the competition was a firm get profit is greater than in competitors or industry. Refer to the result of this research, it can be said that excellence obtained company with based on the price will be achieved when the company operates efficient and able to increase customer satisfaction.

\subsubsection{The effect of efficiency on performance mediated capital structure}

The company performance is the result of work process designed and done deliberately by corporate. Performance reached by companies did not happen on its own but determined by several factors. Performance in this research is measured using the ratio of company ability in getting profit from any assets that are owned. Demands to manage assets in better to be the attention of transportation company. The using of funds on maintain assets company indirectly will affect the efficiency of companies.

Funds used by a company to finance the operating activities, investment including maintenance in accordance with income the period or using other sources. The findings of the research show that capital structure determined by efficiency can increase transportation corporate performance in Indonesia for a period $2013-2015$. The result of the study in line with research of Zeitun and Tian (2007), Aworemi and llori (2008), and Wang dan Liu (2014).

\section{Conclusion}

The transport sector is one sector that has a strategic role in the economic, social, and political. The role of the transport sector in the economy associated with the current distribution of raw materials to the productions center and markets. In the social, transport role in conveying information effectively. In politics, transportation plays a role in strengthening national unity and reducing regional disparities. However, the effectiveness of the role of the transport sector is influenced by the performance of companies within the scope of the sector. This study is expected contributed theoretical in the development of science in transportation field especially determinants factors of affecting performance. 
Based on findings and hypothesis testing, it can be argued that the transport company performance in Indonesia influenced by customer satisfaction and capital structure. Besides that, the company performance also affected by efficiency mediated customer satisfaction and capital structure. The research also found the relationship between efficiency by customer satisfaction. This study did not distinguish between the company base on air transport, land, and sea. Hence, for further research need to distinguish each the company and study about an investment decision and value of the enterprise.

\section{References}

Ahmed Sheikh, Nadeem and Wang, Zongjun. (2011). Determinants of capital structure: An empirical study of firms in manufacturing industry of Pakistan, Managerial Finance, Volume 37 Issue 2, pp.117 - 133.

Abdul G. K. (2012). The relationship of capital structure decisions with firm performance: A study of the engineering sector of Pakistan. International Journal of Accounting and Financial Reporting, Vol. 2, No. 1, pp.245-262.

Akeem, Lawal Babatunde., Terer K, Edwin., Kiyanjui, Monica Wanjiru and Adisa Kayode, Matthew. (2014). Effects of Capital Structure on Firm's Performance: Empirical Study of Manufacturing Companies in Nigeria, Journal of Finance and Investment Analysis, Volume 3, No.4, pp. 39-57.

Akinyomi, O. J. (2013). Effect of Capital Structure on Firms Performance: Evidence from Nigerian Manufacturing Company. International Journal of Innovative Research and Studies. Vol. 2, Issue 9.

Aworemi, J. R and llori, M. O. (2008). An evaluation of the performance of private transport companies in selected Southwestern of Nigeria. African Journal of Business Management Volume 2, No. 8, pp. 131-137.

Aworemi, J. R and llori, M. O. (2008). An evaluation of the performance of private transport companies in selected Southwestern of Nigeria. African Journal of Business Management Vol.2 (8), pp. 131-137.

Babalola Y. A. (2014). Triangulation Analysis of Capital Structure and Firms' Performance in Nigeria. International Proceedings of Economics Development and Research, Volume 69, pp.75-82.

Balian Zahab. (2016). Hukum pengangkutan transportasi sebagai aktivitas (Online) Available: https://balianzahab.wordpress.com/makalah-hukum/hukum-pengangkutan/transportasi-sebagai-aktivitas/

Berger, A. N. and E. Bonaccorsi di Patti. (2006). Capital Structure and Firm Performance: A New Approach to Testing Agency Theory and an Application to the Banking Industry, Journal of Banking and Finance, Vol. 30, pp. 1065-102.

Blanquart, Corinne and Burmeister, Antje. (2009). Evaluating the performance of freight transport: A service approach. Europe Transportation Research Review, Issue 1, pp.135-145.

Boselie, P. and Van der Wiele, T. (2001), Employee perceptions of HRM and the effects on satisfaction and intention to leave. Erasmus Research Institute of Management, ERIM Report Series Research in Management.

Brealey, Myers dan Marcus. (1999). Financial Management; Concepts, Analysis and Capital Investments. 1st Edn., Brierly Jones Nigeria Ltd, Lagos, pp: 361-391.

Chi, Christina G and Gursoy, Dogan. (2009). Employee satisfaction, customer satisfaction, and financial performance: An empirical examination. International Journal of Hospitality Management, Volume 28, Issue 2, Pp. 245-253.

Damodaran. (2001). Corporate Finance; Theory and Practice. 2nd edition. New York Wiley.

Deputi Evaluasi Kinerja Pembangunan. 2012. Kajian Evaluasi Pembangunan Bidang Transportasi Di Indonesia. Badan Perencanaan Pembangunan Nasional Republik Indonesia. (Online) Available www.bappenas.go.id/files/ekps/

Eugene F. Brigham, Joel F. Houston. (2009). Fundamentals of Financial Management, 12th edition, South-Western Cengage Learning.

Fairfield, P.M., Ramnath, S., and Yohn, T.L., (2009). Do Industry-Level Analyses Improve Forecasts of Financial Performance? Journal of Accounting Research, 47 (1), 147-178.

Feng, Ji and Yanru, He. (2013). Study on the Relationships among customer satisfaction, brand loyalty and repurchase intention. Journal of Theoretical and Applied Information Technology, Volume 49, No.1, pp.180-186

Harnen Sulistyo. (2011). Peranan Infrastruktur Transportasi Dalam Mendukung Masterplan Percepatan dan Kualitas Pembangunan Ekonomi di Indonesia. Makalah Kuliah Umum Universitas Brawijaya, Malang.

Hussain Muhammad, Bahadar Shah, and Zia ul Islam. (2014). The Impact of Capital Structure on Firm Performance: Evidence from Pakistan. Journal of Industrial Distribution \& Business, Volume 5, No. 2, pp. 13-20

Indra Bastian. (2006). Sistem Perencanaan dan Penganggaran Pemerintahan Daerah di Indonesia, Salemba Empat, Jakarta

Janic', Milan. (2014). Advanced Transport Systems; Analysis, Modeling, and Evaluation of Performances. Springer, London Heidelberg New York Dordrecht.

Kost, F E. and Rosenwig, J. (1979). Organization and Management: A System and Contingency Approach, McGraw-Hill Inc. US

Kotler, P. (2000). Marketing Management: The Millennium Edition, Prentice Hall International Edition.

Leuthauser, Fredrick A., Weaver, Edward M. (2006). Leveraging Customer Satisfaction through Energy Efficiency. ACEEE Summer Study on Energy Efficiency in Buildings, pp. 231-239.

Modigliani, Franco and Miller, Merton H. (1958). The Cost of Capital, Corporation Finance and the Theory of Investment The American Economic Review, Vol. 48, No. 3, pp. 261-297

Masita, Zaldy Ilham. (2010). Kuartal I, Bisnis logistik tumbuh 15\% (Online) Available: https://www.ipotnews.com/m/article.php?

Murty, AVN, Kiran, Tapesh, and Goel, Ms Nidhi. (2013). Performance Analysis of Airline Services (A critical study of Global Scenario). International Journal of Engineering and Management Research. Volume 3, Issue 6, pp.37-46. 
Mursalim, Abdullah Sanusi, Hendragunawan, dan Nur Alamzah. (2016). Kepuasan pelanggan, efisiensi, dan struktur modal sebagai penentu kinerja perusahaan transportasi Indonesia.

Myers, Stewart C. (2001). Capital Structure. Journal of Economic Perspectives, Volume 15, Number 2, Pp. 81-102.

Nissim, D., and S. Penman. (2001). Ratio analysis and equity valuation: From research to practice. Review of Accounting Studies 6, pp. 109-54.

Oke, O. S. and Afolabi, B. (2011). Capital Structure and Industrial Performance in Nigeria. International Business and Management, Volume 2, No. 1, pp. 100-106.

Penman, S. H., and X. Zhang. (2003). Modeling sustainable earnings and P/E ratios using financial statement information. Working paper, Columbia University

Porter, Michael E. (1980). Competitive Strategy: Techniques for Analyzing Industries and Competitors with a new introduction. The Free Press, New York.

Prakarsa, Lisa Maritseda dan Tarigan, Josua. (2013). Pengaruh kepuasan pelanggan terhadap kinerja keuangan melalui loyalitas pelanggan sebagai variabel intervening pada berbagai sektor perusahaan di Indonesia, Journal of Theoretical and Applied Information Technology, Volume 49, No.1, pp.361-375.

Rangkuti, F. (2003). Measuring Customer Satisfaction. PT. Gramedia Pustaka Utama, Jakarta.

Reinwald, Monica J. (2013). Investigating the Relationship between Operations Efficiency and Customer Satisfaction. Thesis. Department of Industrial and Manufacturing Engineering, Faculty of California Polytechnic State University, San Luis Obispo.

Sadono Sukirno. (2008). Mikro Ekonomi, Teori Pengantar. Edisi ketiga. Divisi Buku Perguruan Tinggi, PT. RajaGrafindo Persada, Jakarta.

Soliman, M. T. (2008). The use of DuPont analysis by market participants. The Accounting Review Volume 83, No.3, pp. 823-53.

Smart, S. B., Megginson, Gitman. (2004). Corporate Finance. Ohio: South-Western, Thomson Learning.

Supranto, J. (2001). Pengukuran Tingkat Kepuasan pelanggan Untuk Menaikkan Pangsa Pasar, Rineke Cipta, Jakarta.

Sundjaja Ridwan S. dan Inge Barlian. (2003). Manajemen Keuangan 1, Edisi kelima. Jakarta: Literata Lintas Media.

Williams, Paul and Naumann, Earl. (2011). Customer satisfaction and business performance: a firm-level analysis, Journal of Services Marketing, Volume 25, Issue 1, pp.20 - 32.

Mulyadi. (2007). Sistem Perencanaan dan Pengendalian Manajemen: Sistem Pelipat gandaan Kinerja Perusahaan. Jakarta, Salemba Empat.

Wang, Zhanzhong and Liu, Xiaoyu. (2014). Comprehensive Cost-benefit Analysis based on the Performance of Drop and Pull Transport, Applied Mechanics and Materials Volume 505-506, pp. 501-506.

Waskita Adiguna. (2009). Peranan transportasi terhadap ekonomi daerah (Online) Available: https://waskitaadiguna.wordpress.com/2009/01/05/peranan-transportasi-terhadap-ekonomi-daerah/

Winarni F dan Sugiarso G. (2005). Manajemen keuangan. Yogyakarta: Media Pressindo.

Wino, Onky Chandra. (2010). Evaluasi Proyek Studi Kasus Trans Jogja (Periode 2008-2011) thesis, Tidak dipublikasikan, Universitas Atma Jaya Yogyakarta.

Wenyra. (2012). Peranan transportasi dalam perkembangan (Online) Available: http://wenyra.blogspot.co.id/2012/10/peranantransportasi-dalam-perkembangan.html

Vergas, Nelson., Cerqueira, António., and Brandão, Elísio. (2015). The Determinants of the Capital Structure of Listed on Stock Market Nonnancial Firms: Evidence for Portugal, Working paper, FEP-UP, School of Economics and Management, University of Porto, Number 555, pp. 1-32.

Zhang, Chuan and Pan, Fei. (2009). The Impacts of customer satisfaction on Profitability: A Study of State-Owned Enterprises in China, Service Science, Volume 1, No. 1, pp.22-30

Zeitun, R. and Tian, G. G.. (2007). Capital structure and corporate performance: evidence from Jordan, Australasian Accounting, Business and Finance Journal, Volume 1, No.4, pp. 40-61. 